\title{
Miranda
}

Revue pluridisciplinaire du monde anglophone /

Multidisciplinary peer-reviewed journal on the English-

speaking world

$8 \mid 2013$

In Umbra Voluptatis : Shades, Shadows, and their

Felicities / Film Adaptations, New Interactions

\section{Martin Sonnabend and Jon Whiteley (eds.), Claude Lorrain, The Enchanted Landscape}

\section{Muriel Adrien}

\section{(2) OpenEdition}

\section{Journals}

\section{Electronic version}

URL: http://journals.openedition.org/miranda/3366

DOI: 10.4000/miranda.3366

ISSN: 2108-6559

\section{Publisher}

Université Toulouse - Jean Jaurès

\section{Electronic reference}

Muriel Adrien, "Martin Sonnabend and Jon Whiteley (eds.), Claude Lorrain, The Enchanted Landscape", Miranda [Online], 8 | 2013, Online since 28 June 2013, connection on 16 February 2021. URL: http:// journals.openedition.org/miranda/3366 ; DOI: https://doi.org/10.4000/miranda.3366

This text was automatically generated on 16 February 2021

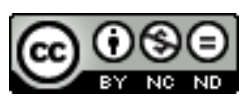

Miranda is licensed under a Creative Commons Attribution-NonCommercial-NoDerivatives 4.0 International License. 


\title{
Martin Sonnabend and Jon Whiteley (eds.), Claude Lorrain, The Enchanted Landscape
}

\author{
Muriel Adrien
}

\section{REFERENCES}

Martin Sonnabend and Jon Whiteley (eds.), Claude Lorrain, The Enchanted Landscape (Oxford: The Ashmolean Museum, Farnham: Lund Humphries, 2011), 216 p, ISBN 978I-848226092-8

1 Claude Lorrain, The Enchanted Landscape is the catalogue of an exhibition of Claude's work at the Ashmolean Museum, Oxford (Oct. 2011-Jan. 2012), and at the Städel Museum, Frankfurt (Feb-May 2012), which are both among the oldest public art galleries of their respective countries. The Ashmolean Museum houses a collection of drawings and prints of one of Claude's great connoisseurs, Chambers Hall, which he bequeathed in 1855. The curators felt it necessary to give new insight on Claude's work, focusing this time on prints and drawings, setting out to trace their similarities and differences with paintings. Prints are given greater attention as research to date has not really studied this aspect of his work, although a taste for them emerged in the nineteenth century. His paintings were well-known during his life, and their impact on British painting, landscape gardening, and on British attitudes towards the countryside, is widely recognized. Claude's influence in Germany is of a lesser scale, as Germans were less familiar with his work, although German artists in Rome and Goethe liked his art.

2 The catalogue includes four essays, two by Martin Sonnabend, one by Jon Whiteley, and one by Christian Rümelin. The first chapter by Martin Sonnabend gives a synthetic overview on Claude's life and art, the second one by Jon Whiteley dwells on drawings, and the $3^{\text {rd }}$ and the $4^{\text {th }}$ by Martin Sonnabend and Christian Rümelin, respectively, analyze the etchings. 
3 Martin Sonnabend's essay gives us the sources of the biography of this quiet painter who kept a frugal and rather uneventful lifestyle despite his substantial income. One of the sources was a German painter, Joachim von Sandrart (1606-1688), who knew Claude as a friend, and the other was a Florentine art scholar, Filippo Baldinucci (1624-1697), who drew his information from Claude's nephew, Joseph Gellée. Another valuable source of information are his will and inventory of his possessions. When trying to delineate the outline of his life, there are periods where biographic information is either hazy or diverges depending on the sources. Hence, perhaps the patchy nature of this chapter. Sonnabend mentions the various influences of Claude, from Agostino Tassi (1578-1644), whose workshop he entered, to Paul Bril (1554-1626) and Adam Elsheimer (1578-1610), as well as his contact with painters and different circles (Northern European artists such as Pieter van Laer (1599-after 1642) or Herman van Swanevelt (c. 1600-1655), Nicolas Poussin (1594-1665)).

His preferred themes were either Arcadian landscapes with peasants in mellow moods, or harbor and maritime views, often combining pendants with morning and evening themes. Indeed, he had the habit of setting off to see the sun rise or set. French visitors to Rome were the first patrons of Claude, then came Roman patricians and cardinals, the Royal Court of Madrid, and ultimately Pope Urban VIII. Beginning in the 1630s, he was highly productive with one painting a month, but their number dropped to three a year afterwards, perhaps due to his gout or because they were larger and more complex. His art of composition was as methodical as his care in archiving his drawings, assembling recurrent features such as the lone tree, the antique edifices, and the distant mountains. The human figures play an active role with an emblematic and narrative quality, but he did not value them per se. Beginning in 1636, the Liber Veritatis eventually included some 200 drawings of his paintings. The reasons for such a venture was to prevent or to prove forgery, as well as to stock motifs.

Claude had little influence in France and Italy although he was highly prized there. It was in England that he left his mark the most. Many prints of Claude's paintings have been in circulation over the centuries, and the Claude glass was invented in England (17). In Germany, he inspired Jakob Philipp Hackert (1737-1807) and Joseph Anton Koch (1768-1839), and Goethe bought a series of Claude's etchings. The chapter ends with a useful chronology, which integrates elements from different biographies.

The second chapter entitled "Claude's drawings" by Jon Whiteley argues that many images were drawn for their own sake and were not just preparatory studies for future paintings. One may wonder whether it was Claude's real intention to consider them as such or if such a comment has been influenced by the current fashion for drawings, which are greatly valued nowadays. As the author says, since many of Claude's drawings have been lost, any sweeping generalizations must be treated with caution. Like with paintings, Claude experienced the influence of Brill's circle in the early 1600 s (Agostino Tassi and Bartholomeus Breenberg (1598-1657), especially his contrasted washes over the initial drawings). Drawings of figures are scarce and somewhat crude (60-61). Drawings were of course either preparatory or kept as records in the Liber Veritatis. The bound books in which he stocked drawings from nature made out of doors, which were meant to supply future paintings with details (59), are described quite closely. Even though the descriptive developments of Whiteley are a little lengthy for the lay reader, they are undoubtedly useful to any scholar desirous of hearing about 
the existing primary documents. This chapter is more interesting for this inventory than for its analysis.

7 In his essay, "Claude Lorrain : the printmaker", Sonnabend draws from research carried out from the early œuvre catalogues published in the nineteenth century as well as the latest 1980 s catalogues. As he says, this research leaves many questions unanswered, offering ample scope for further research. Claude began etching in 1630 at the latest and was most productive between 1634 and 1637. Sonnabend says Claude did 40 etchings in total (Christian Rümelin says 44). He explains the easy and quick intaglio technique : the acid-proof, waxy "etching ground" is incised with an etching needle before being dipped in an acid bath. Along with being an additional source of income, it was also a means for Claude of spreading his reputation. He was familiar with Jacques Callot's (1592-1635) widely circulated etchings, as well as Rembrandt's (1606-1669), although they never met because both were equally sedentary.

8 A classification of his etchings, divided in what has been termed the "broad manner" and the "fine manner", was drawn up by Eckart Knob in around 1960. Sonnabend contends that, although this classification is debatable, it is useful for the period between 1634 and 1637, when Claude explored the medium most intensively. Within his lifetime, very few reproductions of his paintings were made by other printmakers. Claude's own imitations of his paintings adapted to the format and technique and were not always faithful and sometimes experimental. Sonnabend gives us a close technical analysis of Claude's earliest known etching, The Tempest (1630), which reproduces a finished drawing under the influence of Adam Elsheimer. He then goes on to study the context of his fireworks series executed in a very brief period, whether he did them of his own accord or not. Sonnabend examines a series of twelve numbered etchings of six seascapes and six landscapes and tries to date them. Presumably, Claude's printing plates have not survived, although some were in posthumous use in the eighteenth and early nineteenth centuries. Very laudatory of Claude's work, Sonnabend insists on the experimental nature of his work and minimizes any commercial purposes.

In the same way as Jon Whiteley said Claude's drawings were to be regarded for their own sake, Rümelin argues that his etchings cannot be considered as exact reproductions of his paintings (only twelve are), since he often took great liberties with the picture he meant to replicate. He engaged in printing inconsistently and irregularly and according to different methods (thereby defying generalization), mainly in the early 1630s, in 1637 (Rümelin is more assertive than Sonnabend in saying the fireworks series was not a commission), in 1640, in 1650 and in 1662-63. Rümelin endeavors to pinpoint and characterize a relationship between prints and drawings, but fails to do so. He spots the various technical influences by Adam Elsheimer, Hendrick Goult, Bartholomeus Breenbergh, Hercules Piertersz and focuses on the technique used in two examples, The Tempest and The Goats. As well as serving experimental purposes, the prints supplemented Claude's income and enhanced his reputation, sometimes attracting further commissions.

One may regret that, apparently, the three writers have not consulted one another very much before publishing their texts, as one can glean redundancies or slightly diverging conclusions in the four chapters. Nevertheless, this catalogue is highly welcome, as such research had not been undertaken since the 1980s. The technical approach does shed light on Claude's methods and ways of working and gives us the state of his art concerning this aspect of his prints and drawings. Furthermore, seeing so many 
reproductions of Claude's drawings and etchings side by side is highly enjoyable and likely to give food for thought to any art history scholar or art lover.

INDEX

Mots-clés: Ashmolean Museum, Rome, Claude glass, Liber Veritatis, gravure, dessin, eaux-fortes Keywords: Ashmolean Museum, Rome, Claude glass, Liber Veritatis, etchings, engraving, drawing

\section{AUTHORS}

MURIEL ADRIEN

Université de Toulouse 2-Le Mirail

Maître de conferences

muriel.adrien@univ-tlse2.fr 